\title{
Recurrent duplications of the annexin A1 gene (ANXA1) in autism spectrum disorders
}

\author{
Catarina T Correia ${ }^{1,2,3 \dagger}$, Inês C Conceição ${ }^{1,2,3 \dagger}$, Bárbara Oliveira ${ }^{1,2,3}$, Joana Coelho ${ }^{1,2,3}$, Inês Sousa ${ }^{1,2,3}$, \\ Ana F Sequeira ${ }^{1,2,3}$, Joana Almeida ${ }^{4}$, Cátia Café ${ }^{4}$, Frederico Duque ${ }^{4}$, Susana Mouga ${ }^{4,5}$, Wendy Roberts ${ }^{6}, K^{2}$ un Gao ${ }^{7}$, \\ Jennifer K Lowe', Bhooma Thiruvahindrapuram ${ }^{8}$, Susan Walker ${ }^{8}$, Christian R Marshall ${ }^{8}$, Dalila Pinto ${ }^{9}$, \\ John I Nurnberger ${ }^{10}$, Stephen W Scherer ${ }^{8,11}$, Daniel H Geschwind ${ }^{7}$, Guiomar Oliveira ${ }^{4,5}$ and Astrid M Vicente ${ }^{1,2,3^{*}}$
}

\begin{abstract}
Background: Validating the potential pathogenicity of copy number variants (CNVs) identified in genome-wide studies of autism spectrum disorders (ASD) requires detailed assessment of case/control frequencies, inheritance patterns, clinical correlations, and functional impact. Here, we characterize a small recurrent duplication in the annexin A1 (ANXA1) gene, identified by the Autism Genome Project (AGP) study.
\end{abstract}

Methods: From the AGP CNV genomic screen in 2,147 ASD individuals, we selected for characterization an ANXA1 gene duplication that was absent in 4,964 population-based controls. We further screened the duplication in a follow-up sample including 1,496 patients and 410 controls, and evaluated clinical correlations and family segregation. Sequencing of exonic/downstream ANXA1 regions was performed in 490 ASD patients for identification of additional variants.

Results: The ANXA1 duplication, overlapping the last four exons and $3^{\prime} U T R$ region, had an overall prevalence of 11/ 3,643 (0.30\%) in unrelated ASD patients but was not identified in 5,374 controls. Duplication carriers presented no distinctive clinical phenotype. Family analysis showed neuropsychiatric deficits and ASD traits in multiple relatives carrying the duplication, suggestive of a complex genetic inheritance. Sequencing of exonic regions and the $3^{\prime} U T R$ identified 11 novel changes, but no obvious variants with clinical significance.

Conclusions: We provide multilevel evidence for a role of ANXA1 in ASD etiology. Given its important role as mediator of glucocorticoid function in a wide variety of brain processes, including neuroprotection, apoptosis, and control of the neuroendocrine system, the results add ANXA1 to the growing list of rare candidate genetic etiological factors for ASD.

Keywords: ANXA1, Autism, Brain homeostasis, Copy number variants, Duplication, Glucocorticoids

\section{Background}

Family and twin studies strongly support a genetic predisposition for autism spectrum disorders (ASD), a neurodevelopmental disorder characterized by deficits in social interaction, communication, and repetitive behaviour $[1,2]$. However, no genes capable of explaining the majority of cases have been identified to date.

While a prevalent hypothesis has been that ASD risk results from the interaction of multiple common gene

\footnotetext{
* Correspondence: astrid.vicente@insa.min-saude.pt

${ }^{\dagger}$ Equal contributors

'Instituto Nacional de Saúde Doutor Ricardo Jorge, Lisbon 1649-016,

Portugal

${ }^{2}$ Center for Biodiversity, Functional \& Integrative Genomics, Faculty of

Sciences, University of Lisbon, Lisbon 1749-016, Portugal

Full list of author information is available at the end of the article
}

variants, each with a small effect on disorder risk [1,2], in recent years candidate gene studies, genome-wide array screenings, and exome sequencing have brought rare variants to the attention of researchers [2-6]. Rare mutations in specific genes segregating with disorders in families with ASD and/or intellectual disability (ID) have been reported, including SHANK3, NLGN3 and 4, NRXN1, and many others [7-9]. More recently, exome sequencing has uncovered variants in other genes, such as CHD8, GRIN2B, and SCN1A, in ASD individuals [10-12].

Studies from large research groups such as the Autism Genome Project (AGP) international consortium, have highlighted the importance of highly penetrant, rare submicroscopic deletions and duplications, designated copy number variants $(\mathrm{CNVs})$, in autism etiology $[13,14]$. These

\section{Biomed Central}


submicroscopic CNVs, ranging from $1 \mathrm{~kb}$ to $10 \mathrm{mb}$, occur frequently in the human genome, and thus can contribute to genetic diversity and genomic evolution and influence disease risk [13,15]. The AGP study showed that ASD patients have a significantly higher burden of rare genic CNVs, de novo and inherited, when compared to control subjects. The identified CNVs frequently overlapped genes previously implicated in ASD and ID, but also implicated novel genes like SHANK2, SYNGAP1, or DLGAP2. Interestingly, target genes seemed to converge in a small number of affected pathways, with an enrichment of CNVs disrupting functional gene sets involved in cellular proliferation, projection, and motility as well as GTPase/Ras signalling [13].

Because CNVs frequently delete or duplicate brain expressed genes of relevance for autism, it is reasonable to assume that many are likely of pathogenic significance and altogether may explain a substantial fraction of ASD risk [16]. The rigorous assessment of the clinical consequences of CNVs, however, requires the establishment, in large population samples, of recurrence rates in patients, clinical correlations, segregation in families, comparison of frequencies with control databases, and molecular and functional studies.

To assess the clinical significance of rare CNVs identified by the AGP study, we selected, for further characterization, de novo or inherited CNVs that were recurrent in ASD patients but absent or extremely rare in population-based control datasets. Here, we report a small recurrent $\mathrm{CNV}$ duplicating a segment of the annexin A1 gene (ANXA1) in ASD subjects, and its detailed characterization, including frequency in patients and controls, recurrence rates, segregation in families, and breakpoint identification. We further describe the exonic and downstream region sequencing of this gene in a second ASD sample. Annexin A1, previously known as lipocortin 1, is a $37 \mathrm{kDa}$ protein belonging to the annexin protein superfamily. Annexin A1 was initially identified as a potent anti-inflammatory protein, mediating glucocorticoid (GC) actions in the host defence system [17]. Its functional activities, however, far exceed this early discovery, and include cell migration, differentiation, and proliferation, regulation of cell death signalling, phagocytic clearance of apoptotic cells, and carcinogenesis. Annexin A1 has been detected in the brain, where it is thought to have a neuroprotective and anti-inflammatory function [18], and is strongly implicated in the regulation of the neuroendocrine system, in particular the hypothalamus-pituitaryadrenal (HPA) axis control by GCs [19].

\section{Methods}

\section{CNV identification and characterization} Discovery sample

Initial screening for rare, potentially pathogenic CNVs was performed using data from the genome-wide $\mathrm{CNV}$ scan carried out by the AGP consortium [13]. CNV data were available for 2,147 ASD patients of European ancestry that passed all quality control filters. These subjects were recruited at centres in North America and Europe and assessed using the Autism Diagnostic Interview-Revised and Autism Diagnostic Observation Schedule, as previously described [20]. The Autism Simplex Collection database, established in a parallel project, is available for part of the study dataset and includes comprehensive clinical information with detailed diagnostic evaluation and neuropsychological profiling of patients and relatives. To ascertain the prevalence of the CNVs in control individuals, a set of 4,964 populationbased controls from available databases were used for comparison [13]. This set included 1,234 controls from Ottawa (OHI) [21], 1,123 controls from northern Germany (PopGen) [22], 1,287 controls recruited by the Study of Addiction: Genetics and Environment (SAGE) consortium [23], and 1,320 controls from the Children's Hospital of Philadelphia (CHOP) [24].

The patients and controls were genotyped using variable SNP genotyping platforms, with the characteristics and SNP distribution shown in Additional file 1. Patients and their parents were genotyped with the Illumina Infinium $1 \mathrm{M}$-single SNP or the Illumina $1 \mathrm{M}$-duo arrays [25], which include 8 and 11 probes, respectively, within the region analyzed in the present study. CNVs were analyzed using iPattern and QuantiSNP [26] detection algorithms as previously described [13]. The control genotyping data was obtained using Affymetrix Genome-Wide Human SNP 6.0 array $[21,22]$ and Illumina Infinium $1 \mathrm{M}-$ single SNP and $550 \mathrm{~K}$ BeadChip array [23,24] platforms (Additional file 1). Calling parameters and algorithms were the same for patients and controls, and all ANXA1 duplications were subsequently validated using other methods. The platforms used for genotyping patients and controls have a good coverage of at least three of the four duplicated exons (exons 10, 11, and 12) and thus adequately cover the target region (Additional file 1). The Affymetrix Genome-Wide Human SNP 6.0 array, Illumina Infinium $1 \mathrm{M}$-single, and Illumina $1 \mathrm{M}$-duo SNP arrays include, respectively, 6 SNPs and 3 CNV, 8 SNPs, and 11 SNPs probes within the target region. The Illumina $550 \mathrm{~K}$ BeadChip array includes only 5 SNP probes, but was able to detect the duplication in several patients from a followup sample (see below) which was subsequently validated by $\mathrm{qPCR}$, indicating that this platform, with the smallest number of probes, can adequately detect the ANXA1 duplication.

\section{Follow-up sample}

A follow-up patient sample of 1,496 subjects was screened for the ANXA1 duplication, including individuals recruited in Portugal $(n=74)$ [27], individuals from the 
Autism Genetics Resource Exchange collection (AGRE, http://www.agre.org) ( $\mathrm{n}=1,123)$, and non-European individuals from the AGP consortium genome-wide CNV scan [13] $(n=299)$. These patients were diagnosed using the same tools and protocols as the discovery sample. Extensive phenotypic information, including morphologic, cognitive, and adaptive functioning and language measures were available for these patients, as well as basic family history. Autism-related behavioural traits assessed using the Social Responsiveness Scale (SRS) [28] and the Personality Styles and Preferences Questionnaires (PSPQ) [29], were available for some relatives. A total of 410 Portuguese control individuals, not self-reporting an ASD diagnosis, were recruited from health centres and hospitals throughout the country. Informed consent was obtained from all families included in the discovery and follow-up samples, and procedures had approval from institutional review boards.

\section{Ancestry analysis}

Ancestry analysis was carried out using multidimensional scaling as implemented in PLINK (Purcell 2007), utilizing 90,000 autosomal SNP genotypes that were common between the Affymetrix Genome-Wide Human SNP 6.0 array and the Illumina Arrays; 1,397 unrelated HapMap3 samples (typed on the Affymetrix GenomeWide Human SNP 6.0 array) were used as the reference set to infer ethnicities of the cases and controls (including 101 Indian, 497 African, 86 Mexican, 246 Chinese, $165 \mathrm{CEPH}, 87$ African-American, 102 Italian, and 113 Japanese). Further, 1,287 controls from the SAGE consortium, 1,234 from the Ottawa OHI and 1,123 controls from the PopGen studies were plotted with the 26 patients and relatives for whom genome-wide data was available. The CHOP control dataset was not available for ancestry analysis.

\section{CNV validation and screening}

Putative $A N X A 1$ duplications identified in the discovery sample were validated by qPCR using either a predesigned Taqman ${ }^{\odot}$ copy number assay (Applied Biosystems, Hs01220953_cn (chr9:74973810, NCBI Build36, hg18)) or SYBR-Green I-based real time qPCR (Roche, catalogue \# 04707516001). For the Taqman assay, all samples were tested in quadruplicate, and qPCR reactions were performed as duplex reactions with RNase P (Applied Biosystems VIC-TAMRA dual labelled probe) as the reference assay, according to the manufacturer's instructions, on an Applied Biosystems 7900 HT Real Time PCR machine. Results were analyzed using Copy Caller software (v.1.0, Applied Biosystems, USA). SYBR-Green Ibased qPCR was performed using two independent primer pairs designed at the $A N X A 1$ locus and at the FOXP2 locus on chromosome 7 as a diploid control.
Screening of $A N X A 1$ duplications in the Portuguese follow-up sample or control subjects was performed using the same Taqman assay or by Long Range PCR using a SequalPrep Long PCR kit (Invitrogen). Primers were designed using Primer3 software [30]. In the remaining follow-up population, CNVs previously identified by the AGP or by AGRE (called by PennCNV [31] using the Illumina $550 \mathrm{~K}$ BeadChip [5] or Omni-1 Quad genotypes) (Geschwind lab, unpublished data) were confirmed using SYBR-Green I-based qPCR performed on a LightCycler 480 Real-Time PCR system. RNase $\mathrm{P}$ was used as a reference gene and a pooled DNA sample from 94 healthy individuals as calibrator for relative quantification.

\section{Breakpoint mapping}

For breakpoint mapping, ANXA1 duplications were amplified using Long Range PCR and PCR products were sequenced in both directions using fluorescent dye terminators (BigDye Terminator v1.1 Cycle Sequencing Kit, Applied Biosystems, Forest City, CA, USA) and the same PCR primers on the ABI3730xls DNA Analyzer (Applied Biosystems).

\section{Screening for sequence variants Sample}

Sequencing of the $A N X A 1$ coding and downstream regions was performed in a population sample of 490 ASD Portuguese patients recruited and diagnosed as described above, including all patients previously screened by the AGP for CNVs. The frequency of selected variants of particular relevance was estimated in 262 healthy blood donors untested for ASD, with no family history of neuropsychiatric diseases, recruited in Portugal.

\section{Sequencing of coding region and exon/intron boundaries}

The 13 exons, the corresponding exon/intron boundaries and two conserved non-coding regions (chr9:7495715974957417; chr9:74968961-74969803, NCBI Build36, hg18) of the $A N X A 1$ gene were sequenced using Roche 454 massively parallel DNA sequencing. Oligonucleotide primers, tagged with sequencing adaptors and different multiplex identifiers (MIDs) of 10 nucleotide bases, were designed for amplification of 21 ANXA1 gene fragments (average length of $390 \mathrm{bp}$ ) using Primer3 [30] and OligoExplorer (Gene Link) software.

Genomic DNA of the patients was accurately quantified by fluorimetry (Quanti-iT PicoGreen dsDNA Assay Kit, Invitrogen) and then grouped in nine equimolar pools. The nine pools were independently used as templates for amplification of the 21 fragments using primers tagged with different MIDs. Amplification reactions, in a total of 189, were performed with FastStart High Fidelity Taq DNA Polymerase (Roche). The amplicons were purified 
with High Pure 96 UF Cleanup Plates (Roche), visualized in an automated capillary electrophoresis system (Caliper Life Sciences), quantified by use of PicoGreen dsDNA quantitation reagent, and mixed in equimolar pools for clonal amplification by emulsion PCR.

Resulting DNA library beads were loaded into the wells of a PicoTiterPlate device and run in the Genome Sequencer FLX Instrument. Nucleotide reads obtained by massively parallel sequencing were aligned to the reference sequence using Amplicon Variant Analyzer software (Roche). Upon identification of predicted differences between reads and reference, the variants were further analyzed taking into account the following criteria to select high confidence variants: i) the number of reads harbouring the alteration was above the expected value for one allele (one heterozygous individual) in the forward or in the reverse reads and ii) the alteration was detected with both forward and reverse nucleotide reads.

Selected variants with increased frequency in cases vs. control databases were subsequently individually genotyped using Taqman Custom genotyping assays in an ABI PRISM 7900 HT sequence detector system (Applied Biosystems) or Sequenom IPLEX assays with allele detection by mass spectroscopy, using Sequenom MassARRAY technology (Sequenom, San Diego, CA, USA). For the later, primer sequences were designed using Sequenom's MassARRAY Design 3.0 Software and are available upon request.

\section{Downstream gene region sequencing}

The 3' region of ANXA1 (chr9:74975115-74978071, NCBI Build36, hg18) was sequenced by Sanger sequencing (primers available upon request). Contigs were assembled and sequences were aligned using the GAP program v4.11.2 from Staden package [32].

\section{Bioinformatic prediction of variant effect}

Functional impact of novel unique ASD variants was assessed using several prediction tools. Human Splicing Finder [33] and ESE-FINDER [34] were used to investigate potential effects on splicing. Putative changes in transcription factor and microRNA binding sites were assessed using TRANSFAC [35] and miRANDA [36], respectively. Conservation of orthologous positions across diverse species was investigated using Phastcons [37] and overlap with experimental regulatory features was examined on the UCSC Genome browser [38].

\section{Results}

The ANXA1 gene includes 13 exons, encoding four proteincoding transcripts (ENST00000257497, ENST00000376911, ENST00000415424 and ENST00000456643), the largest of which is transcribed from all 13 exons. A duplication encompassing the last four exons of the ANXA1 gene was identified in 5 out of 2,147 unrelated patients from the AGP whole genome study (Families 1-5 in Figure 1). In 4,964 population-based controls from available databases, we did not find this duplication $(P=0.0025)$. Ancestry analysis (Additional file 2) clustered together the 5 AGP patients presenting the duplication with 3,558 European samples from the SAGE, PopGen, and OHI control populations. Restricting the analysis to these ancestry-matched cases and controls, we still found a significant difference in the frequency of the duplication between cases and controls $(P=0.0075)$.

In a follow-up sample including 1,496 ASD patients and 410 control subjects, the ANXA1 duplication was detected in 6 unrelated affected individuals (from Families 6-11 in Figure 1) and none of the controls. Ancestry analysis of these subjects showed that most patients and relatives from the AGRE dataset were spread with non-European SAGE and OHI controls, with a few overlapping with Mexican populations, as expected since some of these patients are Caucasians of Hispanic ethnicity (Additional file 2).

The overall prevalence of the ANXA1 duplications was estimated at $11 / 3,643(\sim 0.30 \%)$ in unrelated ASD patients, in contrast with $0 / 5,374$ in controls $(P=4.64 \times$ $\left.10^{5}\right)$. Both the patient, relative, and control samples had a heterogeneous ancestry, and therefore we did not find evidence for a population effect that could explain the discrepancy of frequency of $A N X A 1$ duplication in patients and controls.

\section{No distinctive clinical phenotype in ANXA1 duplication carriers}

The 13 patients in 11 families identified with the duplication met criteria for autism or ASD diagnosis (Table 1), although the clinical phenotype of the patients carrying the duplication was heterogeneous. Intellectual level ranged from normal in 2 patients to moderate ID in 5 subjects (in 4 patients IQ level was not known). Regarding language function, 9 patients were verbal, but 5 of these presented phrase speech delay, while the remaining 4 presented with severe language impairment, most using only isolated words. Other language abnormalities, such as articulation problems, abnormal prosody and modulation, stuttering, hyperlexia or apraxia were less common. Neurological dysfunction such as seizures, hypotonia or dyskinesias, as well as minor dysmorphologies and language or developmental regression, was present in 5 of the patients. Three patients showed other associated problems, such as mitochondrial dysfunction and gastrointestinal or sleep problems.

To search for potential multiple hits that might modulate clinical expression, genome-wide CNVs were analyzed in the 5 individuals carrying the $A N X A 1$ variant for which this data was available. No additional CNVs 

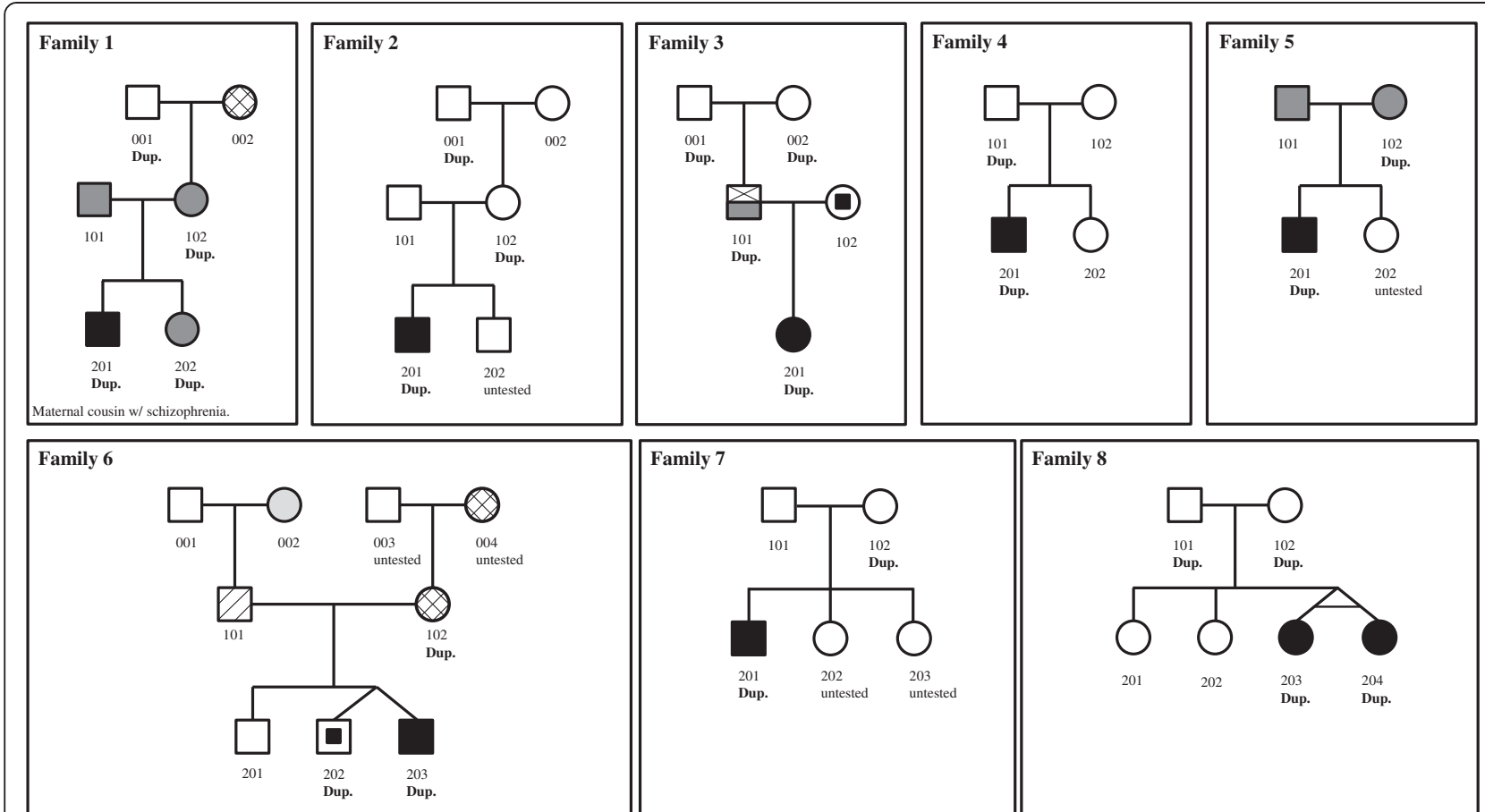

Maternal anxiety symptoms. Maternal aunt w/ psychiatric problems and addiction.

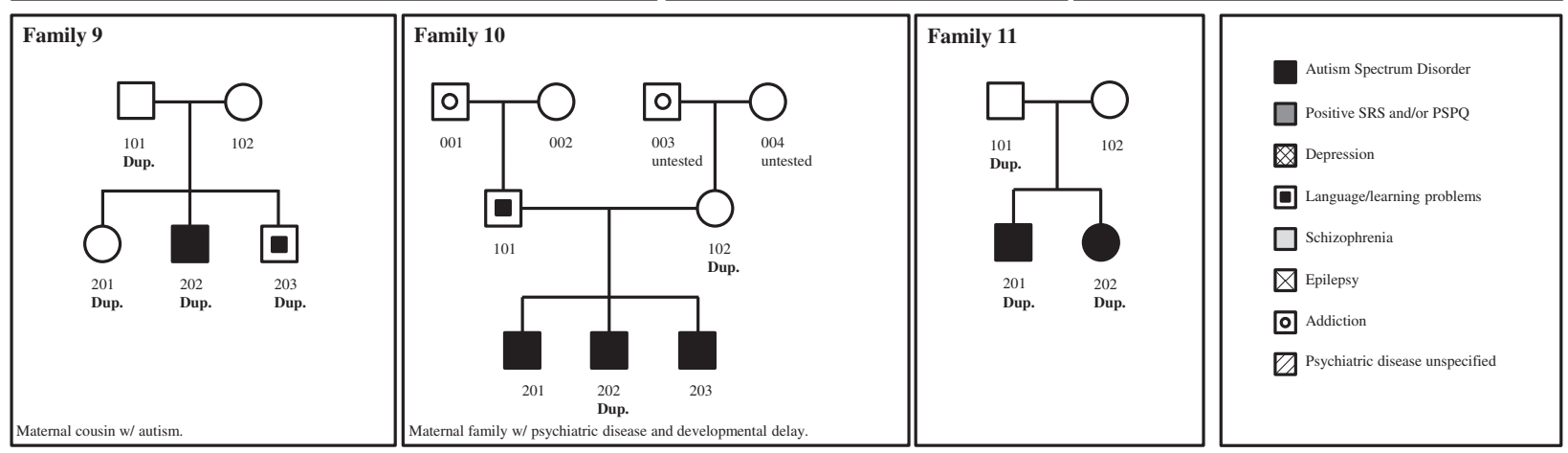

Figure 1 Pedigrees of the 11 unrelated autistic patients and their affected $(n=2)$ and unaffected relatives carrying the $A N X A 1$ duplication. Families 1-5 were part of the AGP whole genome study, while families 6-11 were identified in the follow-up study. All available relatives were tested for the ANXA1 duplication. Dup., individuals carrying the duplication. Untested, individuals for which no DNA sample was available.

with an overlap of less than $50 \%$ with controls were identified that were common between these 5 individuals.

\section{All duplications are inherited}

Family analysis showed that the duplication was inherited in all 13 carrier affected individuals (Figure 1). In 6 patients, the $\mathrm{CNV}$ was inherited from the mother, in 5 from the father, and in the remaining 2 patients, who are monozygotic twins, both parents carried the duplication. No consanguinity has been reported in this family, and the twins had one copy of the duplication each. Grandparents were available for three families, and maternal grandfather transmission was observed in two families (1 and 2), whereas in the third family (family 3 ) both paternal grandparents carried the duplication (Figure 1).
These grandparents were reportedly distant cousins, so there may have been a degree of consanguinity in the family.

Ascertainment of family history further established that all 13 patients had a positive family history of intellectual or neuropsychiatric problems, with cases of ASD, language and learning disability, schizophrenia, depression, and addiction among first or second-degree relatives (Figure 1). In the three families $(1,3$, and 5) where autism traits in parents were evaluated using the SRS [28] and PSPQ [29] questionnaires, the transmitting parent scored positive for at least one of these scales. Two affected (family 10) and 8 unaffected siblings (families 1, $4,6,8$, and 9) were also available for testing. Two of the 3 affected siblings from family 10 did not carry the 
Table 1 Clinical phenotype of the ASD patients with the identified ANXA1 duplication

\begin{tabular}{|c|c|c|c|c|c|c|c|c|c|c|c|c|}
\hline ID & Sex & $\begin{array}{l}\text { Geographical } \\
\text { origin }\end{array}$ & $\begin{array}{l}\text { Reported } \\
\text { ancestry }\end{array}$ & $\begin{array}{l}\text { ASD } \\
\text { type }\end{array}$ & IQ level & Language & $\begin{array}{l}\text { Motor, neurological, } \\
\text { and sensory } \\
\text { problems }\end{array}$ & Physical exam & $\begin{array}{l}\text { Developmental } \\
\text { history }\end{array}$ & $\begin{array}{l}\text { Relevant medical } \\
\text { history }\end{array}$ & $\begin{array}{l}\text { Family } \\
\text { type }\end{array}$ & $\begin{array}{l}\text { Duplication } \\
\text { inheritance }\end{array}$ \\
\hline Fam1_201 & Male & Portugal & European & Autism & $\begin{array}{l}\text { Moderate } \\
\text { ID }\end{array}$ & $\begin{array}{l}\text { Phrase speech delay; } \\
\text { hyperlexia }\end{array}$ & No & Normal & $\begin{array}{l}\text { No regression; } \\
\text { psychomotor } \\
\text { development } \\
\text { delayed }\end{array}$ & $\begin{array}{l}\text { Possible } \\
\text { mitochondrial } \\
\text { disease; sleep } \\
\text { problems; } \\
\text { rumination }\end{array}$ & SPX & Maternal \\
\hline Fam2_201 & Male & Portugal & European & Autism & Mild ID & $\begin{array}{l}\text { Abnormal speech; } \\
\text { only isolated words }\end{array}$ & No & Normal & $\begin{array}{l}\text { No regression; } \\
\text { psychomotor } \\
\text { development } \\
\text { delayed with an } \\
\text { onset at } 2 \text { years }\end{array}$ & None & UNK & Maternal \\
\hline Fam3_201 & Female & Portugal & European & ASD & Normal IQ & No speech delay & Clumsy child & Myopia & $\begin{array}{l}\text { No regression } \\
\text { and no } \\
\text { psychomotor } \\
\text { delayed } \\
\text { development }\end{array}$ & NA & SPX & Paternal \\
\hline Fam4_201 & Male & Canada & European & Autism & $\begin{array}{l}\text { Moderate } \\
\text { ID }\end{array}$ & $\begin{array}{l}\text { Severe language } \\
\text { impairment; speech } \\
\text { and oral motor } \\
\text { deficit (i.e., apraxia); } \\
\text { uses single words }\end{array}$ & $\begin{array}{l}\text { Possible history } \\
\text { of seizures }\end{array}$ & Normal & No regression & NA & UNK & Paternal \\
\hline Fam5_201 & Male & USA & European & Autism & Mild ID & Phrase speech delay & No & Normal & No regression & None & SPX & Maternal \\
\hline Fam6_203 & Male & USA & European & Autism & $\begin{array}{l}\text { Moderately } \\
\text { impaired or } \\
\text { delayed }\end{array}$ & $\begin{array}{l}\text { Verbal; no speech } \\
\text { delay; articulation } \\
\text { problems; abnormal } \\
\text { prosody and } \\
\text { modulation; } \\
\text { stuttering; extreme } \\
\text { to moderate low } \\
\text { score on PPVT }\end{array}$ & $\begin{array}{l}\text { Gait abnormalities; } \\
\text { repetitive movements } \\
\text { (finger; knocking); } \\
\text { sensory abnormalities; } \\
\text { abnormal light touch; } \\
\text { tactile defensiveness; } \\
\text { dyskinesias elicited } \\
\text { lateral foot walking }\end{array}$ & $\begin{array}{l}\text { Epicanthal folds; } \\
\text { left absent tragus; } \\
\text { café au lait }\end{array}$ & $\begin{array}{l}\text { Language } \\
\text { regression at } \\
15 \text { months }\end{array}$ & $\begin{array}{l}\text { Gastroesophageal } \\
\text { reflux; chronic } \\
\text { diarrhoea and } \\
\text { constipation; } \\
\text { allergies and food } \\
\text { sensitivity; sleep } \\
\text { problems }\end{array}$ & SPX & Maternal \\
\hline Fam7_201 & Male & Portugal & European & Autism & Normal IQ & No speech delay & No & Normal & $\begin{array}{l}\text { No regression; } \\
\text { psychomotor } \\
\text { development } \\
\text { delayed }\end{array}$ & Sleep problems & UNK & Maternal \\
\hline Fam8_203 & Female & USA & $\begin{array}{l}\text { Hispanic/ } \\
\text { Latino }\end{array}$ & Autism & NA & $\begin{array}{l}\text { Verbal; phrase } \\
\text { speech delay }\end{array}$ & NA & NA & No regression & NA & SPX & Both \\
\hline Fam8_204 & Female & USA & $\begin{array}{l}\text { Hispanic/ } \\
\text { Latino }\end{array}$ & Autism & NA & $\begin{array}{l}\text { Verbal; phrase } \\
\text { speech delay }\end{array}$ & NA & NA & No regression & NA & SPX & Both \\
\hline Fam9_202 & Male & USA & $\begin{array}{l}\text { Hispanic/ } \\
\text { Latino }\end{array}$ & Autism & NA & $\begin{array}{l}\text { Verbal; phrase } \\
\text { speech delay }\end{array}$ & NA & NA & No regression & NA & MPX & Paternal \\
\hline
\end{tabular}


Table 1 Clinical phenotype of the ASD patients with the identified ANXA1 duplication (Continued)

\begin{tabular}{|c|c|c|c|c|c|c|c|c|c|c|c|c|}
\hline Fam10_202 & Male & USA & $\begin{array}{l}\text { Hispanic/ } \\
\text { Latino }\end{array}$ & Autism & NA & Non-verbal & $\begin{array}{l}\text { Gait abnormalities; } \\
\text { repetitive movements } \\
\text { (hand flapping, finger } \\
\text { movements, body } \\
\text { rocking); increased } \\
\text { acoustic and tactile } \\
\text { sensibility; tactile } \\
\text { defensiveness }\end{array}$ & $\begin{array}{l}\text { Slanted posterior } \\
\text { fontanel; low set } \\
\text { and posterior } \\
\text { angulation ears; } \\
\text { bifid uvula; high } \\
\text { arched palate; } \\
\text { finger clinodactyly }\end{array}$ & No regression & $\begin{array}{c}\text { Neonatal } \\
\text { hyperbilirubinemia } \\
\text { and anaemia }\end{array}$ & MPX & Maternal \\
\hline Fam11_201 & Male & USA & $\begin{array}{l}\text { Hispanic/ } \\
\text { Latino }\end{array}$ & Autism & $\begin{array}{l}\text { Moderately } \\
\text { impaired or } \\
\text { delayed }\end{array}$ & $\begin{array}{l}\text { Verbal; no speech } \\
\text { delay; extreme to } \\
\text { moderate low score } \\
\text { on PPVT }\end{array}$ & NA & Normal & $\begin{array}{l}\text { Developmental } \\
\text { and language } \\
\text { regression }\end{array}$ & NA & MPX & Paternal \\
\hline Fam11_202 & Female & USA & $\begin{array}{l}\text { Hispanic/ } \\
\text { Latino }\end{array}$ & Autism & $\begin{array}{l}\text { Moderately } \\
\text { impaired or } \\
\text { delayed }\end{array}$ & $\begin{array}{l}\text { Non-verbal; phrase } \\
\text { speech delay; } \\
\text { extreme to moderate } \\
\text { low score on PPVT }\end{array}$ & NA & Normal & Regression & NA & MPX & Paternal \\
\hline
\end{tabular}

PPVT, Peabody Picture Vocabulary Test; NA, no information available; SPX, simplex; MPX, multiplex; UNK, unknown. 
duplication. However, this family is heavily loaded in psychopathology both on the paternal and maternal sides and it is thus conceivable that multiple autismassociated variants are segregating in this sibship. Four out of the 8 unaffected siblings also carried the duplication (families 1, 6, and 9). Nevertheless, a closer inspection of the clinical phenotype showed that 3 of the 4 unaffected siblings carrying the duplication had social interaction or cognitive problems: a positive SRS of clinical significance (proband's sister in family 1), documented spelling difficulties and abnormal social behaviour causing parental concern (dizygotic twin in family 6), and language/speech and learning disabilities requiring therapy and educational support (proband's brother in family 9). Only the proband's sister in family 9 carries the duplication but has no indication of any behavioural problem, suggesting that incomplete penetrance and/or modulation by other factors may occur. The remaining 4 tested siblings (in families $4,6,8$ ) not presenting the ANXA1 duplication did not have any psychopathologic diagnosis or cognitive disability. The variability in autism traits, psychopathology, and cognitive deficits in siblings and parents is concordant with the heterogeneity of symptoms in the affected duplication carriers, and more broadly, the notion of complex genetic inheritance [39].

\section{Same ANXA1 breakpoints in all carriers}

A PCR assay with primers pointing outwards from the location of the first and last duplicated SNP in the Illumina Infinium $1 \mathrm{M}$-single SNP array confirmed that the duplication was in tandem and in the direct orientation (Figure 2). Sequencing of this PCR product defined the breakpoints of the duplication and determined its size (7,728 base pairs, spanning chr9:74970292-74978018 from NCBI Build 36, hg18; Figure 2). Although the predictions by PennCNV and QuantiSNP were not the same for all individuals [13], breakpoints were found to be identical in the 13 ASD probands and 15 relative carriers, suggesting a single ancestral event. The distal breakpoint resides in intron 9 (chr9: 74970292; Figure 2), while the proximal end is located 2,891 bp downstream of the gene (chr9: 74978018; Figure 2). A sequence of microhomology of 3 nucleotides (TCA) was present in all the individuals at both breakpoints, and is probably mediating the duplication (Figure 2). The haplotype analysis of a window of 44 SNPs common between the various genotyping platforms, downstream (about $111 \mathrm{~kb}$ ) and upstream (about $133 \mathrm{~kb}$ ) of the duplication, in the 10 probands with genome wide-data available, was done by comparing the haplotypes of the probands, two by two, and calculating the similarity for each pair. The

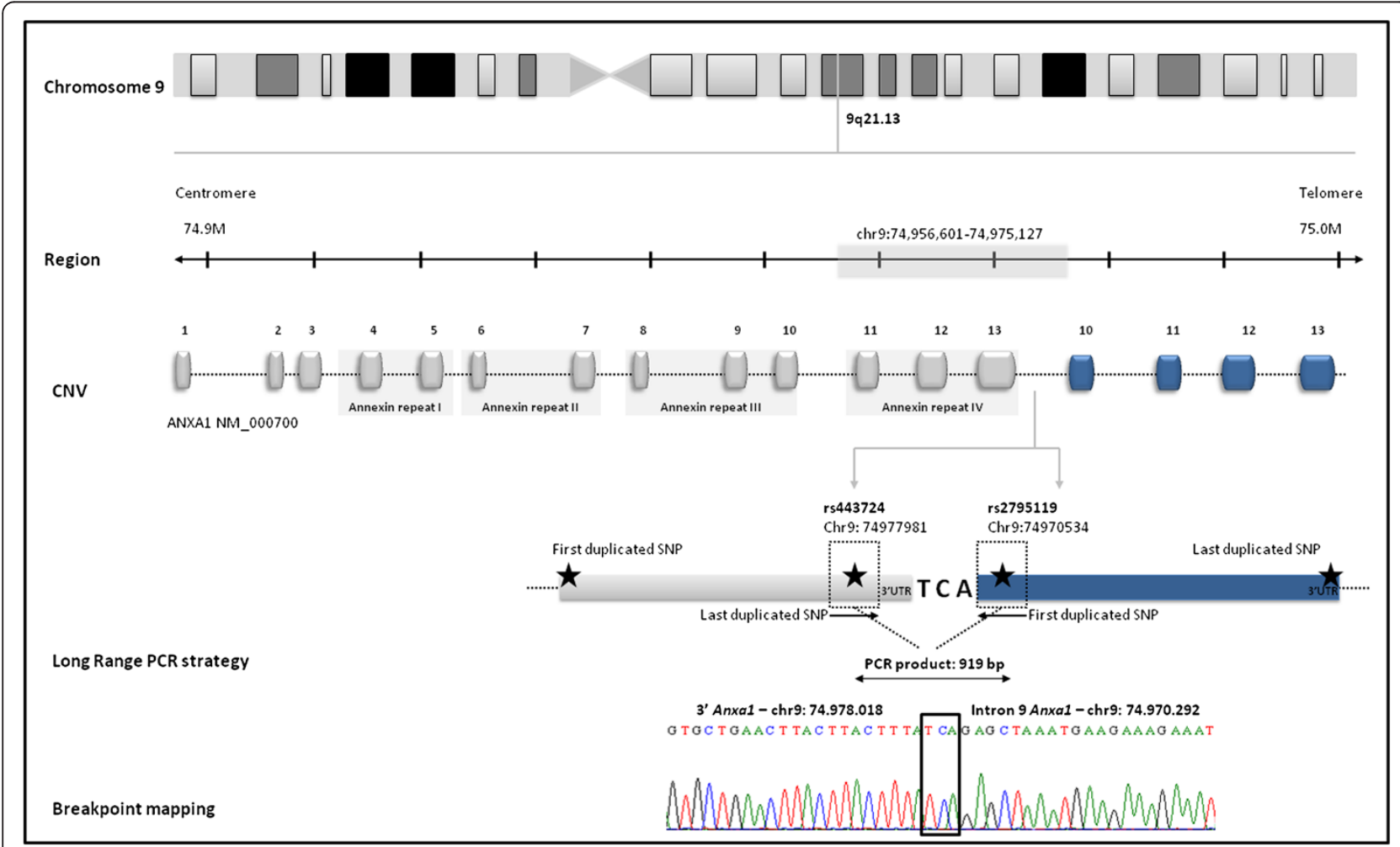

Figure 2 Genomic characterization of ANXA1 duplication: gene location and structure. We performed a Long Range PCR to determine whether the duplication was in tandem, using primers pointing outwards from the location of the first and last duplicated SNP. The four duplicated exons are represented in blue. A sequence of microhomology of three nucleotides (TCA) was also identified and is probably mediating the duplication. 
haplotypes flanking the duplication have an average $88 \%$ similarity.

\section{Identification of novel ANXA1 sequence variants Exonic and splice site regions}

To screen for additional variants in the ANXA1 gene that could be conferring risk for autism, sequencing of the 13 exons, adjacent intron boundaries and the 3'region downstream of the gene was carried out in a cohort of 490 Portuguese ASD patients.

Exon and exon/intron boundaries were sequenced using a DNA pooling approach. A total of 735,987 nucleotide reads were obtained, corresponding to a mean coverage of $73 \times$ per fragment per individual. Forty-two alterations were identified by sequencing of exonic and splice site regions, 32 of which were considered high confidence (see Methods for criteria) and were further considered.

Based on an increased frequency of the variant in cases vs. control databases, 28 of the 32 variants were selected for validation by individual genotyping in the same ASD sample and in 262 Portuguese control individuals. Five rare variants that were not listed in SNP databases and were absent in the panel of 262 control individuals were identified (Table 2). Four of these variants were intronic and in silico analysis did not determine any putative functional role; one variant was located in the region upstream of the gene. This latter variant mapped to a conserved residue 48 bp upstream of the transcription start site and overlapped with several experimentally confirmed regulatory features, such as a DNA hypersensitivity cluster, transcription binding sites, and histone marks, suggesting a potential regulatory role. TRANSFAC [35] analysis predicted potential alterations in transcription factor binding sites, including the abolishment of a binding site for the vitamin D receptor and the creation of an orthodenticle homeobox binding site (OTX), previously implicated in psychiatric disorders [40,41]. Additionally, 3 SNPs absent in the control sample and described as monomorphic in the Hapmap CEU population from dbSNP were further evaluated for a potential functional role (Table 2). One SNP (rs2795115) was located in the 5'UTR region but no functional alterations were predicted by in silico analysis. Another SNP (rs10119605) was located in intron 11-12, and a third one (rs10114350) was mapped to a splice site sequence 7 bp upstream of exon 4, in a highly conserved position in primates and altering an intronic splicing enhancer.

\section{Intergenic region}

The 3' region downstream the 3'UTR of ANXA1, which is also included in the duplication and spans approximately 3,000 bp, has 31 nucleotide positions varying between $H$. sapiens and $P$. troglodytes. Considering the mean autosomal single nucleotide divergence between these two species ( 1.33\%; [42]), which would predict 39 nucleotide changes, we observed a trend toward a purifying selection in this region. Sequencing identified a total of 21 variants, 15 of which were previously reported SNPs and 6 were novel variants found in 8 individuals (Table 2). One of these novel variants was exclusive of 2 monozygotic twins (both affected). One of the 6 novel variants was highly conserved, however none of the 6 changes had predicted functional consequences by in silico analysis using SNP Nexus [43] and TRANSFAC [35], suggesting that these are probably neutral variants.

\section{Discussion}

In this study, a $7.7 \mathrm{~kb}$ inherited duplication on chromosome 9q21.13, encompassing the four last exons of the ANXA1 gene, was identified in 11 out of 3,643 unrelated autistic patients but in none of 5,374 healthy controls. Ancestry analysis did not provide evidence for a population stratification effect explaining the presence of the duplication exclusively in patients. We also carefully assessed the possibility that absence in control samples from available databases was the result of false negatives due to genotyping platform differences. SNP coverage was adequate in the duplicated region in several of the platforms (8 to 11 SNPs), while the array targeting the smallest number of SNPs was able to detect the duplication in some of the patients. The intriguing duplication frequency in cases versus its absence in controls thus prompted us to further investigate the potential contribution of variants in this gene for autism etiology.

As is commonly observed in ASD, the identified ANXA1 duplication was not associated with a distinctive phenotype, but patients showed a heterogeneous clinical presentation in terms of ASD phenotype, intellectual disability, language difficulties, neurodevelopmental regression, or dysmorphic features [44-46]. A clear pattern of transmission of the duplication with ASD was not observed; however, a more meticulous analysis of the phenotype in available relatives showed that many parents and siblings carrying the duplication present a broader autism phenotype, language disability, cognitive deficits, or neuropsychiatric problems. One single family included cases of ASD with and without the duplication. However, this family was heavily burdened with neuropsychiatric disease on both the maternal and paternal side, and therefore it is plausible that several etiological factors affected the family simultaneously. In light of present day literature, these observations suggest that a low penetrance $A N X A 1$ duplication may be associated with a broader autism phenotype and co-morbidities, with other unidentified factors interacting with the duplication to influence its phenotypic expression. Supporting this 
Table 2 Identified ANXA1 novel variants and SNPs absent in controls

\begin{tabular}{|c|c|c|c|c|c|c|c|c|c|}
\hline $\begin{array}{l}\text { Genomic } \\
\text { position } \\
\text { (hg18) }\end{array}$ & $\begin{array}{l}\text { Nucleotide } \\
\text { change }\end{array}$ & $\begin{array}{l}\text { Amino } \\
\text { acid } \\
\text { change }\end{array}$ & Location & Transcript & Novel/SNP & $\begin{array}{c}\text { Frequency } \\
\text { cases }\end{array}$ & Genotype & In silico analysis & $\begin{array}{l}\text { PhastCons } \\
\text { (primates) }\end{array}$ \\
\hline 74956445 & $G>A$ & - & $\begin{array}{l}5 \text { ' of the } \\
\text { gene }\end{array}$ & ENST00000257497 & Novel $^{1}$ & 0.002 & Homo & $\begin{array}{c}\text { TFBS abolished: VDR, } \\
\text { CAR, PXR; NF-Y, C-myb, } \\
\text { Crx; TFBS created: HNF6, } \\
\text { Nkx6-2, OTX, CdXA }\end{array}$ & 0.48 \\
\hline 74956718 & CTA > Del.CTA & - & Intron 1-2 & ENST00000257497 & Novel $^{1}$ & 0.002 & Het & - & 0.23 \\
\hline 74962617 & $C>T$ & - & 5'UTR & ENST00000376911 & rs $2795115^{1}$ & 0.002 & Het & - & 0.014 \\
\hline 74964058 & $\mathrm{~T}>\mathrm{C}$ & - & intron 3-4 & ENST00000257497 & rs10114350' & 0.002 & Het & $\begin{array}{l}\text { splice-site SNP (ENSEMBL), } \\
\text { ISRE down (pfSNP) }\end{array}$ & 0.81 \\
\hline 74972178 & $G>A$ & - & intron 10-11 & ENST00000257497 & Novel $^{1}$ & 0.005 & Het & - & 0.1 \\
\hline 74972626 & $T>G$ & - & Intron 11-12 & ENST00000257497 & Novel $^{1}$ & 0.002 & Het & - & 0.18 \\
\hline 74973075 & $G>C$ & - & Intron 11-12 & ENST00000257497 & rs10119605 & 0.002 & Het & - & 0.11 \\
\hline 74973545 & $\mathrm{~T}>\mathrm{C}$ & - & Intron 11-12 & ENST00000257497 & Novel $^{1}$ & 0.002 & Het & - & NA \\
\hline 74975361 & $G>A$ & - & 3' (intergenic) & - & Novel & 0.002 & Het & - & 0.05 \\
\hline 74975609 & $\mathrm{~T}>\mathrm{A}$ & - & 3' (intergenic) & - & Novel & 0.002 & Het & - & 0.78 \\
\hline 74975645 & $\mathrm{~T}>\mathrm{C}$ & - & 3' (intergenic) & - & rs149272288 & 0.001 & Het & - & 0.014 \\
\hline 74975873 & $C>T$ & - & 3' (intergenic) & - & rs9792653 & 0.051 & Het & - & NA \\
\hline 74975882 & $C>T$ & - & 3' (intergenic) & - & rs143327464 & 0.004 & Het & - & NA \\
\hline 74976171 & $C>T$ & - & 3' (intergenic) & - & rs113627562 & 0.004 & Het & - & NA \\
\hline 74976222 & $A>G$ & - & 3' (intergenic) & - & rs72737044 & 0.017 & Het/Homo & - & 0.18 \\
\hline 74976536 & $C>T$ & - & 3' (intergenic) & - & Novel & 0.001 & Het & - & 0.03 \\
\hline 74976574 & $\mathrm{~T}>\mathrm{C}$ & - & 3' (intergenic) & - & rs78798837 & 0.002 & Het & - & NA \\
\hline 74977215 & $\mathrm{~T}>\mathrm{C}$ & - & 3' (intergenic) & - & Novel & 0.001 & Het & - & 0.006 \\
\hline 74977218 & $C>T$ & - & 3' (intergenic) & - & rs 146061737 & 0.001 & Het & - & 0.003 \\
\hline 74977655 & $A>G$ & - & 3' (intergenic) & - & rs114240435 & 0.002 & Het & - & 0 \\
\hline 74977680 & $C>A$ & - & 3' (intergenic) & - & rs114833327 & 0.001 & Het & - & NA \\
\hline 74977840 & $G>A$ & - & 3' (intergenic) & - & rs11143512 & 0.465 & Het/Homo & - & NA \\
\hline 74977852 & $A>G$ & - & 3' (intergenic) & - & Novel & 0.001 & Het & - & 0.01 \\
\hline 74977888 & $C>G$ & - & 3' (intergenic) & - & rs17653109 & 0.089 & Het/Homo & - & 0.07 \\
\hline 74977928 & $C>T$ & - & 3' (intergenic) & - & rs75260654 & 0.023 & Het & - & NA \\
\hline 74977965 & $C>G$ & - & 3' (intergenic) & - & Novel & 0.001 & Het & - & 0.08 \\
\hline 74977981 & $C>T$ & - & 3' (intergenic) & - & rs4443724 & 1 & Homo & - & 0.003 \\
\hline 74977990 & $C>T$ & - & 3' (intergenic) & - & rs116224215 & 0.007 & Het & - & NA \\
\hline 74978003 & $C>T$ & - & 3' (intergenic) & - & rs4285546 & 0.04 & Het/Homo & - & 0.003 \\
\hline
\end{tabular}

${ }^{1}$ Absent in a panel of 262 control individuals; Homo, homozygous; Het, heterozygous; TFBS, transcription factor binding site; NA, not available.

possibility, there is growing evidence indicating that, in addition to clinical overlap between clinical entities in the neuropsychiatric spectrum and ASD $[28,47]$, shared heritability and overlapping genetic factors may lead to variable expressivity and incomplete penetrance in families of ASD subjects [48-52].

Taking into consideration the multiple hit model proposed for ASD [53,54], we searched for modulating risk or protective genetic factors that might regulate the clinical expression of the $A N X A 1$ duplication. No other $\mathrm{CNV}$ in common between these individuals was identified in the AGP whole genome study suggesting that a double hit is a rare occurrence or that such modulating factors are heterogeneous among these patients. Future exome sequencing will help clarify this issue.

The exact same location of the breakpoints in all duplication carriers indicates that it is likely an ancestral event - a hypothesis that is further supported by the similar haplotypes flanking the duplication. The region of microhomology is consistent with studies showing that the breakpoints in $40 \%$ of duplications and $70 \%$ of deletions had regions with 1 to 30 bp of microhomology $[55,56]$.

Extensive sequencing of exonic and regulatory regions was carried out to identify additional sequence variants 
in the ANXA1 gene that might contribute to ASD etiology, as well as any changes co-occurring with the inherited CNVs. Sequencing uncovered a number of novel variants and previously reported monomorphic SNPs absent from a panel of control individuals. One variant upstream of the gene disrupts or creates binding sites for transcription factors such as the vitamin D receptor and OTX, which have been implicated in psychiatric disorders including autism [40,41], thus potentially modulating ANXA1 expression. Based on conservation and functional in silico prediction tools, some of these variants are of potential interest, although no obvious pathogenic variants have been identified.

Abnormal post-translational processing of $A N X A 1$ has been previously observed in individuals with Fragile $\mathrm{X}$ syndrome [57], which frequently presents with autistic symptomatology. Expression studies will be necessary to assess if this variant alters $A N X A 1$ expression and to elucidate the potential impact of the duplication. The latest ENCODE results [58] show DNase I hypersensitivity clusters in the distal breakpoint region, suggesting a possible disruption of a regulatory sequence. These, and other mechanisms by which the ANXA1 duplication can be deleterious, need to be clarified.

Annexin A1, a member of the annexin superfamily that contains 13 calcium or calcium and phospholipidbinding proteins, has been implicated in many diverse cellular functions, including anti-inflammatory effects $[18,59,60]$, cell growth [61], apoptosis [62], membrane fusion, endocytosis, and exocytosis [63]. The consequences of annexin A1 dysregulation could therefore influence multiple pathways, some of which have been previously linked to autism pathophysiology. Annexin A1 was first identified as a GC-inducible protein and a potential mediator of the anti-inflammatory actions of these steroid hormones $[17,64]$, ensuring an appropriate level of activation of innate immune cells [59] and/or transducing a stimulatory signal to promote T-cell activation. Immunological dysfunction has been a recognized feature in ASD, supported by the observation of abnormal levels of circulating brain autoantibodies and anti-inflammatory markers as well as neuroglial activation and neuroinflammation in several brain regions in ASD patients [65-68]. Annexin A1 also controls the non-inflammatory phagocytosis of apoptotic neurons and promotes the resolution of inflammatory microglial activation [18], thus regulating neuronal apoptosis during neurological development and the mature brain. Furthermore, annexin A1 plays a fundamental role in the regulation of the HPA axis, effecting the negative feedback of GC at the level of the pituitary gland and hypothalamus [69], and thus modulating the secretion of corticotrophin (adrenocorticotropic hormone) and its hypothalamic releasing hormones, corticotrophin-releasing hormone and arginine vasopressin [19]. There is evidence that the HPA axis, as part of the limbic system which is the neural basis for emotion and social functioning, is impaired in autistic children [70-75]. For instance, abnormal responses of autistic subject to stress as well as increased levels of cortisol secretion and adrenocorticotropic hormone in serum of autistic males have been reported [76-80]. Abnormalities in corticotropic cell number and structure in male $A N X A 1$ knockout mice further support this hypothesis [81].

\section{Conclusions}

The identification of a recurrent tandem duplication of the $A N X A 1$ gene in autistic patients which is not present in a very large set of controls, supported by family observations of co-occurrence of the variant with neuropsychiatric disability, suggests an involvement of this gene in the etiology of ASD. The variety of physiological mechanisms where annexin A1 has been implicated implies a fundamental role of this molecule in brain homeostasis, with specific aspects clearly relevant for the pathophysiology of ASD. Overall, the results described herein constitute supporting evidence for $A N X A 1$ as one more etiological risk factor for ASD, warranting further functional investigation.

\section{Additional files}

\begin{abstract}
Additional file 1: Genotyping platform coverage of ANXA1
duplicated region. SNPS that are common between the platforms used in the AGP discovery sample, the AGRE follow-up sample, and control datasets are represented (black triangle). SNPs covered exclusively by the Illumina 1 M-duo array (purple triangle), the Illumina Omni-1 Quad array (green triangle) and the Affymetrix Genome-Wide Human SNP 6.0 array (blue triangle) are also represented, as well as the $26 \mathrm{bp}$ CNV probes (blue circle) of Affymetrix Genome-Wide Human SNP 6.0 array.

Additional file 2: Multidimensional scaling analysis results, using 1,397 unrelated HapMap3 samples as reference set to infer ethnicities, control samples from SAGE consortium, Ottawa (OHI), Northern Germany (PopGen), and the ASD cases and relatives with the ANXA1 duplication (AGP and AGRE).
\end{abstract}

\section{Abbreviations}

AGP: Autism Genome Project; AGRE: Autism Genetics Resource Exchange; ANXA1: Annexin A1; ASD: Autism spectrum disorders; CHOP: Children's hospital of Philadelphia; CNVs: Copy number variants; ENCODE: Encyclopedia of DNA elements; GC: Glucocorticoid; HPA axis: Hypothalamus-pituitaryadrenal axis; ID: Intellectual disability; kb/mb: kilobase/megabase; kDa: Kilodalton; MIDs: Multiplex identifiers; OHI: Ottawa heart institute; PSPQ: Personality styles and preferences questionnaire; SAGE: Study of addiction, genetic and environment; SRS: Social responsiveness scale.

\section{Competing interests}

The authors declare that they have no competing interests.

\section{Authors' contributions}

CTC and ICC carried out CNV validation, breakpoint mapping, segregation, and sequence analysis. BO, JC, IS, and AFS participated in CNV and sequence analysis and manuscript revision. $\mathrm{KG}, \mathrm{JKL}, \mathrm{BT}$, and $\mathrm{SW}$ participated in CNV and phenotypic data analysis, and manuscript revision. JA, CC, FD, SM, GO, and WR recruited and performed the clinical assessment of patients' and relatives, and revised the manuscript. CM, DP, JIN, SWS, and DHG contributed 
patient samples, participated in the interpretation of results and manuscript revision. AMV, CTC, and ICC carried out the study design, interpretation of data, and the drafting of the manuscript. All authors read and approved the final manuscript.

\section{Acknowledgments}

We gratefully acknowledge the children with ASD and their families for their collaboration. We thank the AGP investigators for sharing data, resources, and scientific discussions. The AGP study was funded by Autism Speaks (USA), the Health Research Board (HRB, Ireland; AUT/2006/1, AUT/2006/2, PD/2006/48), The Medical Research Council (MRC, UK), Genome Canada/ Ontario Genomics Institute and the Hilibrand Foundation (USA). Additional support for individual groups was provided by the US National Institutes of Health (NIH Grants: HD055751, HD055782, HD055784, MH52708, MH55284, MH061009, MH06359, MH066673, MH080647, MH081754, MH66766, NS026630, NS042165, NS049261), the Canadian Institutes for Health Research (CIHR), Assistance Publique - Hôpitaux de Paris (France), Autism Speaks UK, Canada Foundation for Innovation/Ontario Innovation Trust, Deutsche Forschungsgemeinschaft (Grant: Po 255/17-4) (Germany), EC Sixth FP AUTISM MOLGEN, Fundação Calouste Gulbenkian (Portugal), Fondation de France, Fondation FondaMental (France), Fondation Orange (France), Fondation pour la Recherche Médicale (France), Fundação para a Ciência e Tecnologia (Portugal), the Hospital for Sick Children Foundation and University of Toronto (Canada), INSERM (France), Institut Pasteur (France), the Italian Ministry of Health (convention 181 of 19 October 2001), the John P Hussman Foundation (USA), McLaughlin Centre (Canada), Ontario Ministry of Research and Innovation (Canada), the Seaver Foundation (USA), the Swedish Science Council, the Centre for Applied Genomics (Canada), the Utah Autism Foundation (USA), and the Wellcome Trust core award 075491/Z/04 (UK). We gratefully acknowledge the resources provided by the Autism Genetic Resource Exchange (AGRE) Consortium and the participating AGRE families. The Autism Genetic Resource Exchange is a program of Autism Speaks and is supported, in part, by grant 1U24MH081810 from the National Institute of Mental Health to Clara M. Lajonchere (PI). Catarina Correia and Inês C. Conceição are supported by grants SFRH/BPD/64281/2009 and SFRH/BPD/ 74739/2010, respectively, from Fundação para a Ciência e Tecnologia. Ethical approval was obtained from: i) the Ethics Committee at Hospital Pediátrico de Coimbra (Portugal) for the Portuguese cases not included in AGP; ii) the Ethics Committee at the Instituto Nacional de Saúde Doutor Ricardo Jorge (Portugal) for the Portuguese controls; and iii) the Institutional Review Board at UCLA for the AGRE sample. The control data from $\mathrm{OHI}$, approved by the Research Ethics Board of the University of Ottawa Heart Institute; PopGen, approved by the Ethics Committee of the Medical Faculty of Kiel and by the data protection officer of the University Hospital Schleswig-Holstein; CHOP, approved by the Children's Hospital of Philadelphia Institutional Review Board; and SAGE, approved by the Institutional Review Board at each contributing institution (COGA, FSCD, and COGEND) are published and available. The AGP data involves several research centres and has already been published; the data is available.

\section{Author details}

${ }^{1}$ Instituto Nacional de Saúde Doutor Ricardo Jorge, Lisbon 1649-016, Portugal. ${ }^{2}$ Center for Biodiversity, Functional \& Integrative Genomics, Faculty of Sciences, University of Lisbon, Lisbon 1749-016, Portugal. ${ }^{3}$ Instituto Gulbenkian de Ciência, Oeiras 2780-156, Portugal. ${ }^{4}$ Unidade de Neurodesenvolvimento e Autismo, Centro de Desenvolvimento da Criança e Centro de Investigação e Formação Clínica, Hospital Pediátrico, Centro Hospitalar e Universitário de Coimbra, Coimbra 3000-602, Portugal. ${ }^{5}$ Institute for Biomedical Imaging and Life Sciences, Faculty of Medicine, University of Coimbra, Coimbra 3000-548, Portugal. ${ }^{6}$ Autism Research Unit, The Hospital for Sick Children and Bloorview Kids Rehab, University of Toronto, Toronto, Ontario M5G 1X8, Canada. ${ }^{7}$ Program in Neurogenetics, Department of Neurology, Center for Autism Research and Treatment, Semel Institute, David Geffen School of Medicine at UCLA, Los Angeles, CA 90095, USA. ${ }^{8}$ The Centre for Applied Genomics and Program in Genetics and Genome Biology, The Hospital for Sick Children, Toronto, Ontario M5G 0A4, Canada. ${ }^{9}$ Departments of Psychiatry, and Genetics and Genomic Sciences, Seaver Autism Center, and the Mindich Child Health \& Development Institute, Mount Sinai School of Medicine, New York, NY 10029, USA. ${ }^{10}$ Institute of Psychiatric Research, Departments of Psychiatry and Medical and Molecular Genetics, Indiana University School of Medicine, Indianapolis, IN 46202, USA.
${ }^{11}$ Department of Molecular Genetics and the McLaughlin Centre, University of Toronto, Toronto, ON M5S 1A1, Canada.

Received: 26 August 2013 Accepted: 17 March 2014 Published: 10 April 2014

\section{References}

1. Abrahams BS, Geschwind DH: Advances in autism genetics: on the threshold of a new neurobiology. Nat Rev Genet 2008, 9:341-355.

2. Freitag CM, Staal W, Klauck SM, Duketis E, Waltes R: Genetics of autistic disorders: review and clinical implications. Eur Child Adolesc Psychiatry 2010, 19:169-178.

3. Glessner JT, Wang K, Cai G, Korvatska O, Kim CE, Wood S, Zhang H, Estes A, Brune CW, Bradfield JP, Imielinski M, Frackelton EC, Reichert J, Crawford EL, Munson J, Sleiman PM, Chiavacci R, Annaiah K, Thomas K, Hou C, Glaberson W, Flory J, Otieno F, Garris M, Soorya L, Klei L, Piven J, Meyer KJ, Anagnostou $E$, Sakurai $T$, et al: Autism genome-wide copy number variation reveals ubiquitin and neuronal genes. Nature 2009, 459:569-573.

4. Autism Genome Project C, Szatmari P, Paterson AD, Zwaigenbaum L, Roberts W, Brian J, Liu XQ, Vincent JB, Skaug JL, Thompson AP, Senman L, Feuk L, Qian C, Bryson SE, Jones MB, Marshall CR, Scherer SW, Vieland VJ, Bartlett C, Mangin LV, Goedken R, Segre A, Pericak-Vance MA, Cuccaro ML, Gilbert JR, Wright HH, Abramson RK, Betancur C, Bourgeron T, Gillberg C, Leboyer $M$, et al: Mapping autism risk loci using genetic linkage and chromosomal rearrangements. Nat Genet 2007, 39:319-328.

5. Wang K, Zhang H, Ma D, Bucan M, Glessner JT, Abrahams BS, Salyakina D, Imielinski M, Bradfield JP, Sleiman PM, Kim CE, Hou C, Frackelton E, Chiavacci R, Takahashi N, Sakurai T, Rappaport E, Lajonchere CM, Munson J, Estes A, Korvatska O, Piven J, Sonnenblick LI, Alvarez Retuerto Al, Herman El, Dong H, Hutman T, Sigman M, Ozonoff S, Klin A, et al: Common genetic variants on $5 \mathrm{p} 14.1$ associate with autism spectrum disorders. Nature 2009, 459:528-533.

6. Weiss LA, Arking DE, Daly MJ, Chakravarti A, Gene Discovery Project of Johns Hopkins \& the Autism Consortium: A genome-wide linkage and association scan reveals novel loci for autism. Nature 2009, 461:802-808.

7. Betancur C: Etiological heterogeneity in autism spectrum disorders: more than 100 genetic and genomic disorders and still counting. Brain Res 2011, 1380:42-77.

8. Buxbaum JD: Multiple rare variants in the etiology of autism spectrum disorders. Dialogues Clin Neurosci 2009, 11:35-43.

9. Marshall CR, Scherer SW: Detection and characterization of copy number variation in autism spectrum disorder. Methods Mol Biol 2012, 838:115-135.

10. Neale BM, Kou Y, Liu L, Ma'ayan A, Samocha KE, Sabo A, Lin CF, Stevens C, Wang LS, Makarov V, Polak P, Yoon S, Maguire J, Crawford EL, Campbell NG, Geller ET, Valladares O, Schafer C, Liu H, Zhao T, Cai G, Lihm J, Dannenfelser R, Jabado O, Peralta Z, Nagaswamy U, Muzny D, Reid JG, Newsham I, Wu Y, et al: Patterns and rates of exonic de novo mutations in autism spectrum disorders. Nature 2012, 485:242-245.

11. O'Roak BJ, Deriziotis P, Lee C, Vives L, Schwartz JJ, Girirajan S, Karakoc E, Mackenzie AP, Ng SB, Baker C, Rieder MJ, Nickerson DA, Bernier R, Fisher SE, Shendure J, Eichler EE: Exome sequencing in sporadic autism spectrum disorders identifies severe de novo mutations. Nat Genet 2011, 43:585-589.

12. O'Roak BJ, Vives L, Girirajan $S$, Karakoc E, Krumm N, Coe BP, Levy R, Ko A, Lee C, Smith JD, Turner EH, Stanaway IB, Vernot B, Malig M, Baker C, Reilly B, Akey JM, Borenstein E, Rieder MJ, Nickerson DA, Bernier R, Shendure J, Eichler EE: Sporadic autism exomes reveal a highly interconnected protein network of de novo mutations. Nature 2012, 485:246-250.

13. Pinto D, Pagnamenta AT, Klei L, Anney R, Merico D, Regan R, Conroy J, Magalhaes TR, Correia C, Abrahams BS, Almeida J, Bacchelli E, Bader GD, Bailey AJ, Baird G, Battaglia A, Berney T, Bolshakova N, Bölte S, Bolton PF, Bourgeron T, Brennan S, Brian J, Bryson SE, Carson AR, Casallo G, Casey J, Chung $\mathrm{BH}$, Cochrane L, Corsello $\mathrm{C}$, et al: Functional impact of global rare copy number variation in autism spectrum disorders. Nature 2010, 466:368-372.

14. Sebat J, Lakshmi B, Malhotra D, Troge J, Lese-Martin C, Walsh T, Yamrom B, Yoon S, Krasnitz A, Kendall J, Leotta A, Pai D, Zhang R, Lee YH, Hicks J, Spence SJ, Lee AT, Puura K, Lehtimäki T, Ledbetter D, Gregersen PK, Bregman J, Sutcliffe JS, Jobanputra V, Chung W, Warburton D, King MC, 
Skuse D, Geschwind DH, Gilliam TC, et al: Strong association of de novo copy number mutations with autism. Science 2007, 316:445-449.

15. Conrad DF, Pinto D, Redon R, Feuk L, Gokcumen O, Zhang Y, Aerts J, Andrews TD, Barnes C, Campbell P, Fitzgerald T, Hu M, lhm CH, Kristiansson K, Macarthur DG, Macdonald JR, Onyiah I, Pang AW, Robson S, Stirrups K Valsesia A, Walter K, Wei J, Wellcome Trust Case Control C, Tyler-Smith C, Carter NP, Lee C, Scherer SW, Hurles ME: Origins and functional impact of copy number variation in the human genome. Nature 2010, 464:704-712.

16. Malhotra D, Sebat J: CNVs: harbingers of a rare variant revolution in psychiatric genetics. Cell 2012, 148:1223-1241.

17. Flower RJ, Blackwell GJ: Anti-inflammatory steroids induce biosynthesis of a phospholipase A2 inhibitor which prevents prostaglandin generation. Nature 1979, 278:456-459.

18. McArthur S, Cristante E, Paterno M, Christian H, Roncaroli F, Gillies GE, Solito E: Annexin A1: a central player in the anti-inflammatory and neuroprotective role of microglia. J Immunol 2010, 185:6317-6328.

19. Buckingham JC, John CD, Solito E, Tierney T, Flower RJ, Christian H, Morris J: Annexin 1, glucocorticoids, and the neuroendocrine-immune interface. Ann N Y Acad Sci 2006, 1088:396-409.

20. Anney R, Klei L, Pinto D, Regan R, Conroy J, Magalhaes TR, Correia C, Abrahams BS, Sykes N, Pagnamenta AT, Almeida J, Bacchelli E, Bailey AJ, Baird G, Battaglia A, Berney T, Bolshakova N, Bölte S, Bolton PF, Bourgeron T, Brennan S, Brian J, Carson AR, Casallo G, Casey J, Chu SH, Cochrane L, Corsello C, Crawford EL, Crossett A, et al: A genome-wide scan for common alleles affecting risk for autism. Hum Mol Genet 2010, 19:4072-4082

21. Stewart AF, Dandona S, Chen L, Assogba O, Belanger M, Ewart G, LaRose R, Doelle H, Williams K, Wells GA, McPherson R, Roberts R: Kinesin family member 6 variant Trp719Arg does not associate with angiographically defined coronary artery disease in the Ottawa Heart Genomics Study. J Am Coll Cardiol 2009, 53:1471-1472.

22. Krawczak M, Nikolaus S, von Eberstein H, Croucher PJ, El Mokhtari NE, Schreiber S: PopGen: population-based recruitment of patients and controls for the analysis of complex genotype-phenotype relationships. Community Genet 2006, 9:55-61.

23. Bierut $\sqcup$, Agrawal A, Bucholz KK, Doheny KF, Laurie C, Pugh E, Fisher S, Fox L, Howells W, Bertelsen S, Hinrichs AL, Almasy L, Breslau N, Culverhouse RC, Dick DM, Edenberg HJ, Foroud T, Grucza RA, Hatsukami D, Hesselbrock V, Johnson EO, Kramer J, Krueger RF, Kuperman S, Lynskey M, Mann K, Neuman RJ, Nöthen MM, Nurnberger II Jr, Porjesz B, et al: A genome-wide association study of alcohol dependence. Proc Natl Acad Sci U S A 2010, 107:5082-5087.

24. Shaikh TH, Gai X, Perin JC, Glessner JT, Xie H, Murphy K, O'Hara R, Casalunovo T, Conlin LK, D'Arcy M, Frackelton EC, Geiger EA, HaldemanEnglert C, Imielinski M, Kim CE, Medne L, Annaiah K, Bradfield JP, Dabaghyan E, Eckert A, Onyiah CC, Ostapenko S, Otieno FG, Santa E, Shaner JL, Skraban R, Smith RM, Elia J, Goldmuntz E, Spinner NB, et al: High-resolution mapping and analysis of copy number variations in the human genome: a data resource for clinical and research applications. Genome Res 2009, $19: 1682-1690$

25. Anney R, Klei L, Pinto D, Almeida J, Bacchelli E, Baird G, Bolshakova N, Bölte S, Bolton PF, Bourgeron T, Brennan S, Brian J, Casey J, Conroy J, Correia C, Corsello C, Crawford EL, de Jonge M, Delorme R, Duketis E, Duque F, Estes A, Farrar P, Fernandez BA, Folstein SE, Fombonne E, Gillbert J, Gillberg C, Glessner JT, Green A, et al: Individual common variants exert weak effects on the risk for autism spectrum disorderspi. Hum Mol Genet 2012, 21:4781-4792.

26. Colella S, Yau C, Taylor JM, Mirza G, Butler H, Clouston P, Bassett AS, Seller A, Holmes CC, Ragoussis J: QuantiSNP: an Objective Bayes Hidden-Markov Model to detect and accurately map copy number variation using SNP genotyping data. Nucleic Acids Res 2007, 35:2013-2025.

27. Oliveira G, Ataíde A, Marques C, Miguel TS, Coutinho AM, Mota-Vieira L, Gonçalves E, Lopes NM, Rodrigues V, Carmona Da Mota H, Vicente AM: Epidemiology of autism spectrum disorder in Portugal: prevalence, clinical characterization, and medical conditions. Dev Med Child Neurol 2007, 49:726-733.

28. Constantino JN, Todd RD: Intergenerational transmission of subthreshold autistic traits in the general population. Biol Psychiatry 2005, 57:655-660.

29. Hurley RS, Losh M, Parlier M, Reznick JS, Piven J: The broad autism phenotype questionnaire. J Autism Dev Disord 2007, 37:1679-1690.

30. Rozen S, Skaletsky H: Primer3 on the WWW for general users and for biologist programmers. Methods Mol Biol 2000, 132:365-386.
31. Wang K, Li M, Hadley D, Liu R, Glessner J, Grant SF, Hakonarson H, Bucan M: PennCNV: an integrated hidden Markov model designed for highresolution copy number variation detection in whole-genome SNP genotyping data. Genome Res 2007, 17:1665-1674.

32. Bonfield JK, Smith K, Staden R: A new DNA sequence assembly program. Nucleic Acids Res 1995, 23:4992-4999.

33. Desmet FO, Hamroun D, Lalande M, Collod-Béroud G, Claustres M, Béroud C: Human Splicing Finder: an online bioinformatics tool to predict splicing signals. Nucleic Acids Res 2009, 37:e67.

34. Cartegni L, Wang J, Zhu Z, Zhang MQ, Krainer AR: ESEfinder: A web resource to identify exonic splicing enhancers. Nucleic Acids Res 2003, 31:3568-3571.

35. Matys V, Fricke E, Geffers R, Gössling E, Haubrock M, Hehl R, Hornischer K, Karas D, Kel AE, Kel-Margoulis OV, Kloos DU, Land S, Lewicki-Potapov B, Michael H, Münch R, Reuter I, Rotert S, Saxel H, Scheer M, Thiele S, Wingender E: TRANSFAC: transcriptional regulation, from patterns to profiles. Nucleic Acids Res 2003, 31:374-378.

36. John B, Enright AJ, Aravin A, Tuschl T, Sander C, Marks DS: Human MicroRNA targets. PLoS Biol 2004, 2:e363.

37. Siepel A, Bejerano G, Pedersen JS, Hinrichs AS, Hou M, Rosenbloom K, Clawson H, Spieth J, Hillier LW, Richards S, Weinstock GM, Wilson RK, Gibbs RA, Kent WJ, Miller W, Haussler D: Evolutionarily conserved elements in vertebrate, insect, worm, and yeast genomes. Genome Res 2005, 15:1034-1050

38. Kent WJ, Sugnet CW, Furey TS, Roskin KM, Pringle TH, Zahler AM, Haussler D: The human genome browser at UCSC. Genome Res 2002, 12:996-1006

39. Berg JM, Geschwind DH: Autism genetics: searching for specificity and convergence. Genome Biol 2012, 13:247.

40. Yan J, Feng J, Craddock N, Jones IR, Cook EH, Goldman D, Heston LL, Chen J, Burkhart P, Li W, Shibayama A, Sommer SS: Vitamin D receptor variants in 192 patients with schizophrenia and other psychiatric diseases. Neurosci Lett 2005, 380:37-41.

41. Liu X, Malenfant P, Reesor C, Lee A, Hudson ML, Harvard C, Qiao Y, Persico AM, Cohen IL, Chudley AE, Forster-Gibson C, Rajcan-Separovic E, Lewis ME, Holden JJ: 2p15-p16.1 microdeletion syndrome: molecular characterization and association of the OTX1 and XPO1 genes with autism spectrum disorders. Eur J Hum Genet 2011, 19:1264-1270.

42. Nachman MW, Crowell SL: Estimate of the mutation rate per nucleotide in humans. Genetics 2000, 156:297-304.

43. Chelala C, Khan A, Lemoine NR: SNPnexus: a web database for functional annotation of newly discovered and public domain single nucleotide polymorphisms. Bioinformatics 2009, 25:655-661.

44. Cook EH, Scherer SW: Copy-number variations associated with neuropsychiatric conditions. Nature 2008, 455:919-923.

45. Kumar RA, KaraMohamed S, Sudi J, Conrad DF, Brune C, Badner JA, Gilliam TC, Nowak NJ, Cook EH, Dobyns WB, Christian SL: Recurrent 16p11.2 microdeletions in autism. Hum Mol Genet 2008, 17:628-638.

46. Noor A, Whibley A, Marshall CR, Gianakopoulos PJ, Piton A, Carson AR, OrlicMilacic M, Lionel AC, Sato D, Pinto D, Drmic I, Noakes C, Senman L, Zhang X, Mo R, Gauthier J, Crosbie J, Pagnamenta AT, Munson J, Estes AM, Fiebig A, Franke A, Schreiber S, Stewart AF, Roberts R, McPherson R, Guter SJ, Cook EH Jr, Dawson G, Schellenberg GD, et al: Disruption at the PTCHD1 Locus on Xp22.11 in Autism spectrum disorder and intellectual disability. Sci Transl Med 2010, 2:49ra68.

47. Virkud YV, Todd RD, Abbacchi AM, Zhang Y, Constantino JN: Familial aggregation of quantitative autistic traits in multiplex versus simplex autism. Am J Med Genet B Neuropsychiatr Genet 2009, 150B:328-334.

48. Vassos E, Collier DA, Holden S, Patch C, Rujescu D, St Clair D, Lewis CM: Penetrance for copy number variants associated with schizophrenia. Hum Mol Genet 2010, 19:3477-3481.

49. Pickles A, Starr E, Kazak S, Bolton P, Papanikolaou K, Bailey A, Goodman R, Rutter M: Variable expression of the autism broader phenotype: findings from extended pedigrees. J Child Psychol Psychiatry 2000, 41:491-502.

50. Cross-Disorder Group of the Psychiatric Genomics Consortium, Lee SH, Ripke S, Neale BM, Faraone SV, Purcell SM, Perlis RH, Mowry BJ, Thapar A, Goddard ME, Witte JS, Absher D, Agartz I, Akil H, Amin F, Andreassen OA, Anjorin A, Anney R, Anttila V, Arking DE, Asherson P, Azevedo MH, Backlund L, Badner JA, Bailey AJ, Banaschewski T, Barchas JD, Barnes MR, Barrett TB, Bass N, et al: Genetic relationship between five psychiatric disorders estimated from genome-wide SNPs. Nat Genet 2013, 45:984-994. 
51. Consortium C-DGPG: Consortium GROoPG, Identification of risk loci with shared effects on five major psychiatric disorders: a genome-wide analysis. Lancet 2013, 381:1371-1379.

52. Nava C, Keren B, Mignot C, Rastetter A, Chantot-Bastaraud S, Faudet A, Fonteneau E, Amiet C, Laurent C, Jacquette A, Whalen S, Afenjar A, Périsse D, Doummar D, Dorison N, Leboyer M, Siffroi JP, Cohen D, Brice A, Héron D, Depienne C: Prospective diagnostic analysis of copy number variants using SNP microarrays in individuals with autism spectrum disorders. Eur J Hum Genet 2014, 22:71-78.

53. Girirajan S, Rosenfeld JA, Cooper GM, Antonacci F, Siswara P, Itsara A, Vives L, Walsh T, McCarthy SE, Baker C, Mefford HC, Kidd JM, Browning SR, Browning BL, Dickel DE, Levy DL, Ballif BC, Platky K, Farber DM, Gowans GC, Wetherbee JJ, Asamoah A, Weaver DD, Mark PR, Dickerson J, Garg BP Ellingwood SA, Smith R, Banks VC, Smith W, et al: A recurrent 16p12.1 microdeletion supports a two-hit model for severe developmental delay. Nat Genet 2010, 42:203-209.

54. Leblond CS, Heinrich J, Delorme R, Proepper C, Betancur C, Huguet G, Konyukh M, Chaste P, Ey E, Rastam M, Anckarsäter H, Nygren G, Gillberg IC, Melke J, Toro R, Regnault B, Fauchereau F, Mercati O, Lemière N, Skuse D, Poot M, Holt R, Monaco AP, Järvelä I, Kantojärvi K, Vanhala R, Curran S, Collier DA, Bolton P, Chiocchetti A, et al: Genetic and functional analyses of SHANK2 mutations suggest a multiple hit model of autism spectrum disorders. PLOS Genet 2012, 8:e1002521.

55. Conrad DF, Bird C, Blackburne B, Lindsay S, Mamanova L, Lee C, Turner DJ, Hurles ME: Mutation spectrum revealed by breakpoint sequencing of human germline CNVs. Nat Genet 2010, 42:385-391.

56. Kim PM, Lam HY, Urban AE, Korbel JO, Affourtit J, Grubert F, Chen X, Weissman S, Snyder M, Gerstein MB: Analysis of copy number variants and segmental duplications in the human genome: Evidence for a change in the process of formation in recent evolutionary history. Genome Res 2008, 18:1865-1874

57. Sun HT, Cohen S, Kaufmann WE: Annexin-1 is abnormally expressed in fragile $X$ syndrome: two-dimensional electrophoresis study in lymphocytes. Am J Med Genet 2001, 103:81-90.

58. ENCODE Project Consortium, Bernstein BE, Birney E, Dunham I, Green ED, Gunter C, Snyder M: An integrated encyclopedia of DNA elements in the human genome. Nature 2012, 489:57-74.

59. Perretti M, D'Acquisto F: Annexin A1 and glucocorticoids as effectors of the resolution of inflammation. Nat Rev Immunol 2009, 9:62-70.

60. Perretti M, Gavins FN: Annexin 1: an endogenous anti-inflammatory protein. News Physiol Sci 2003, 18:60-64.

61. Tyburczy ME, Kotulska K, Pokarowski P, Mieczkowski J, Kucharska J, Grajkowska W, Roszkowski M, Jozwiak S, Kaminska B: Novel proteins regulated by $\mathrm{mTOR}$ in subependymal giant cell astrocytomas of patients with tuberous sclerosis complex and new therapeutic implications. Am J Pathol 2010, 176:1878-1890.

62. Solito E, Kamal A, Russo-Marie F, Buckingham JC, Marullo S, Perretti M: A novel calcium-dependent proapoptotic effect of annexin 1 on human neutrophils. FASEB J 2003, 17:1544-1546.

63. Gerke V, Moss SE: Annexins: from structure to function. Physiol Rev 2002, 82:331-371.

64. Blackwell GJ, Carnuccio R, Di Rosa M, Flower RJ, Parente L, Persico P: Macrocortin: a polypeptide causing the anti-phospholipase effect of glucocorticoids. Nature 1980, 287:147-149.

65. Goines P, Van de Water J: The immune system's role in the biology of autism. Curr Opin Neurol 2010, 23:111-117.

66. Pardo CA, Vargas DL, Zimmerman AW: Immunity, neuroglia and neuroinflammation in autism. Int Rev Psychiatry 2005, 17:485-495.

67. Persico AM, Van de Water J, Pardo CA: Autism: where genetics meets the immune system. Autism Res Treat 2012, 2012:486359.

68. Silva SC, Correia C, Fesel C, Barreto M, Coutinho AM, Marques C, Miguel TS, Ataide A, Bento C, Borges L, Oliveira G, Vicente AM: Autoantibody repertoires to brain tissue in autism nuclear families. J Neuroimmunol 2004, 152:176-182.

69. John CD, Christian HC, Morris JF, Flower RJ, Solito E, Buckingham JC: Annexin 1 and the regulation of endocrine function. Trends Endocrinol Metab 2004, 15:103-109.

70. Aylward EH, Minshew NJ, Goldstein G, Honeycutt NA, Augustine AM, Yates KO, Barta PE, Pearlson GD: MRI volumes of amygdala and hippocampus in non-mentally retarded autistic adolescents and adults. Neurology 1999, 53:2145-2150.
71. Herbert J: Neurosteroids, brain damage, and mental illness. Exp Gerontol 1998, 33:713-727.

72. Hrdlicka M, Dudova I, Beranova I, Lisy J, Belsan T, Neuwirth J, Komarek V, Faladova L, Havlovicova M, Sedlacek Z, Blatny M, Urbanek T: Subtypes of autism by cluster analysis based on structural MRI data. Eur Child AdolesC Psychiatry 2005, 14:138-144.

73. Palmen SJ, van Engeland $H$, Hof PR, Schmitz C: Neuropathological findings in autism. Brain 2004, 127:2572-2583.

74. Rojas DC, Smith JA, Benkers TL, Camou SL, Reite ML, Rogers SJ: Hippocampus and amygdala volumes in parents of children with autistic disorder. Am J Psychiatry 2004, 161:2038-2044.

75. Waterhouse L, Fein D, Modahl C: Neurofunctional mechanisms in autism. Psychol Rev 1996, 103:457-489.

76. Corbett BA, Mendoza S, Abdullah M, Wegelin JA, Levine S: Cortisol circadian rhythms and response to stress in children with autism. Psychoneuroendocrinology 2006, 31:59-68.

77. Corbett BA, Schupp CW, Levine S, Mendoza S: Comparing cortisol, stress, and sensory sensitivity in children with autism. Autism Res 2009, 2:39-49.

78. Curin JM, Terzić J, Petković ZB, Zekan L, Terzić IM, Susnjara IM: Lower cortisol and higher ACTH levels in individuals with autism. J Autism Dev Disord 2003, 33:443-448.

79. Iwata K, Matsuzaki H, Miyachi T, Shimmura C, Suda S, Tsuchiya KJ, Matsumoto K, Suzuki K, Iwata Y, Nakamura K, Tsujii M, Sugiyama T, Sato K, Mori N: Investigation of the serum levels of anterior pituitary hormones in male children with autism. Mol Autism 2011, 2:16.

80. Richdale $A L$, Prior MR: Urinary cortisol circadian rhythm in a group of high-functioning children with autism. J Autism Dev Disord 1992, 22:433-447.

81. Morris JF, Omer S, Davies E, Wang E, John C, Afzal T, Wain S, Buckingham JC. Flower RJ, Christian HC: Lack of annexin 1 results in an increase in corticotroph number in male but not female mice. J Neuroendocrinol 2006, 18:835-846.

doi:10.1186/2040-2392-5-28

Cite this article as: Correia et al:: Recurrent duplications of the annexin A1 gene (ANXA1) in autism spectrum disorders. Molecular Autism 2014 5:28.

\section{Submit your next manuscript to BioMed Central and take full advantage of:}

- Convenient online submission

- Thorough peer review

- No space constraints or color figure charges

- Immediate publication on acceptance

- Inclusion in PubMed, CAS, Scopus and Google Scholar

- Research which is freely available for redistribution 